\title{
Online Learning for English Language Learners During Covid-19 Pandemic in Muhammadiyah University of Surabaya
}

\author{
\#1 Waode Hamsia $\quad{ }^{*}$ Y Yatim Riyanto $\quad{ }^{*}$ Fajar Arianto \\ ${ }^{*}$ Doctoral Program, Department of Technology of Education, State University of Surabaya, Indonesia \\ ${ }^{*}$ Lecturer, Department of English Education, \\ University of Muhammadiyah Surabaya, Indonesia \\ ${ }^{*}$ Lecturer, Department of Education of Technology, \\ State University of Surabaya, Indonesia \\ ${ }^{*}$ Lecturer, Department of Management of Education, \\ State University of Surabaya, Indonesia
}

\begin{abstract}
An existence of a government policy for study from home in the COVID-19 pandemic era has disrupted the conventional learning process. Online learning was an alternative that can overcome the problem of the spread of COVID-19 pandemic in universities. A purpose of this research was English language learners that needed online learning during COVID-19 pandemic in Muhammadiyah University of Surabaya. Learning English, especially in speaking skills, is an important skill in English as a foreign language (EFL). One thing that also influenced the behaviour of English language learners in the online learning model was Computer Self Efficacy (CSE). Students' confidence used computers that are also a success factor in online learning. This research was conducted at the medical faculty of the Muhammadiyah University of Surabaya. The method used descriptive qualitative. The subjects of this research were 80 students of the first semester students in medical faculty in Muhammadiyah University of Surabaya. This research showed the results that the implementation of the online learning model can provide many English learning activities independently at anywhere and anytime. The learning English online for students were very interesting. Therefore, it can be increased students' motivation to practice speaking in English.
\end{abstract}

Keywords: English language learners, Online Learning, Computer Self Efficacy, Speaking Skill, Covid-19 Pandemic

DOI: $10.7176 / \mathrm{JEP} / 12-9-10$

Publication date:March $31^{\text {st }} 2021$

\section{INTRODUCTION}

The era of corona virus disease 2019 (Covid-19) outbreak that had hit 215 countries in the world, presents its own challenges for educational institutions, especially university at the Muhammadiyah University of Surabaya. Lectures must be held with a scenario that is able to prevent physical contact between students and lecturers and students and students (Firman, F., \& Rahayu, S., 2020). According to Milman (2015) the use of digital technology can allow students and lecturers to carry out the learning process even though they are in the different places. The form of lectures that can be used as a solution during the Covid-19 pandemic is online learning. According to Moore, Dickson-Deane, \& Galyen (2011). Online learning is learning that uses an internet network with accessibility, connectivity, flexibility, and the ability to generate various types of learning interactions. Research conducted by Zhang et al., (2004) shows that the use of the internet and multimedia technology is able to change the way of conveying knowledge and can be an alternative to learning carried out in conventional classrooms.

Online learning is learning that is able to bring together students and lecturers to carry out learning interactions with the help of the internet (Kuntarto, 2017). At the implementation level, online learning requires the support of mobile devices such as smartphones or Android phones, laptops, computers, tablets, and iPhones that can be used to access information anytime and anywhere (Gikas \& Grant, 2013). Higher education during the Work From Home (WFH) period needs to carry out strengthening of online learning (Darmalaksana, 2020). Online learning has been a demand for education for several years (He, Xu, \& Kruck, 2014). Online learning is needed in learning in the era of industrial revolution 4.0 (Pangondian, RA, Santosa, PI, \& Nugroho, E., 2019). Online learning is a form of distance learning that utilizes technology telecommunications and information, for example the internet, CD-ROOM (Molinda, 2005).

A lecturer as a facilitator has the most important role in learning in the classroom as well as outside the classroom. Therefore, the lecturers must ensure that learning for all students can be effective by utilizing technology and information. It emphasises that it is not enough for teachers to just have ICT competencies and be able to teach them to students. Rather, the lecturers need to be able to help students become collaborative, problem 
solving, creative learners through using ICT in order to be effective citizens and members of the workforce (UNESCO, 2011b). So that for learning needs, a lecturer must be able to apply information and computer technology (ICT) in the field of education to improve learning competencies and encourage learners to be collaborative, able to solve problems and be more creative in using ICT to be prepared to enter the world of work.

The online learning model does not only use available technology but lecturers as facilitators must be able to find better ways to support students by always motivating to achieve learning goals being able to communicate in English to be more competitive and have the opportunity to win challenges in the world of work in this era. industry 4.0. 'Too often the opportunities and advantages of the use of technology in the learning process are poorly exploited" (Oliver \& Herrington, 2003, p. 111). Ideally blended learning experiences should be participative, not just interactive so that the process of cognition and collaboration are both enhanced; " thinking and working together creates learning" (Allen, 2010). Therefore, the good preparation and the right decision are very important not only for efficient use but also for a quality learning experience for students and improving academic achievement.

In learning English for speaking skill is an important skill as a Foreign Language (English for Foreign Language). Language skills separate into two kinds that are receptive and productive. Receptive consists of listening and reading skills. Productive consists of speaking and writing skills. All of the skills are important in communication, including English communication. That is how the four skills are taught in English as a Foreign Language (EFL). One of the most important skills in EFL is speaking skill. According to the Oxford dictionary, speaking is the action of conveying information or expressing one's thoughts and feelings in spoken language. From the definition, it includes that speaking is expression in sending messages from a speaker towards listeners. Sending message in speaking uses verbal language. Because of that, communication in speaking way should be accurate. The accuracy can decide the success of communication. Teaching speaking needs to know about obstacles that may occur in the learning process. Some problems come from the internal of language learners and others come from the external of language learners.

In teaching speaking has a challenge to make suitable classroom hours, because usually in college students that they learn English lesson only one meeting (100 minutes) in a week. Therefore, the language learners do in a limit time and they do not maximize in their ability in English. Therefore, they do not have the maximal time to practice in the outside of the classroom. They do not have time to practice outside the classroom because they do not have suitable partner to speak in English. In a fact, they would speak in their native language. This is a very important problem to find a solution. So that new students for the 2020/2021 academic year are given online learning supplements for English courses with integrated skills using the English Discoveries platform. The English learning can be obtained intensively every day for 24 hours in a very effective and efficient way. It makes the language learners can still learn through online classes by accessing learning applications using English Discoveries through their devices. This system has been proven to be effective especially in the Covid 19 pandemic.

Especially in online learning using English Discoveries every week, they have to study 1 unit. In 1 unit there are about 7 lessons so that every day they have to complete 1 lesson for 3 steps, namely explore, practice and test. Based on activities that are routinely carried out by students every day, it can provide many opportunities to learn using online information technology, so that they can improve their English skills, especially speaking skills. The language learners are expected to be able to use spoken communication in English in the surrounding environment for daily conversations. This can be very useful that is not only in work but also for continuing to study abroad. Speaking is often spontaneous, open and developing. In line with this, Tarigan (1990) argues that speaking is the ability to pronounce articulated sounds or words to express, say and convey thoughts, ideas and feelings. Furthermore, Tarigan (1990) states that: speaking is the skill to convey messages through spoken language. Trying to explain more about speaking, Burn \& Joyce (1997) and Luoma (2004, p. 2) define speaking, namely: speaking as an interactive process of constructing meaning that involves producing, receiving and processing information. It's from and meaning is dependent on the context in which it occurs, including the participants themselves, the physical environment, and the purposes for speaking".

Speaking in general can be interpreted as conveying one's intentions (ideas, thoughts, heart's contents) to another by using spoken language so that the meaning can be understood by others. In the Webster's third international dictionary, it is stated that speaking skill is the act of expressing the idea in the words and conversation. Meanwhile, in the chambers dictionary, it was explained that speaking skill is for communication. Moreover, Arthur Hughes defines in his book language learning states that speaking is the ability to interact successfully in that language. Trying to explain more about speaking, Burn \& Joyce (1997) and Luoma (2004, p. 2) define speaking, namely: speaking as an interactive process of constructing meaning that involves producing, receiving and processing information. Its form and meaning were dependent on the context in which it occurs, including the participants themselves, the physical environment, and the purposes for speaking. According to him, speaking is often done spontaneously, openly and developing. In line with this, Tarigan (1990) argues that Speaking is the ability to pronounce articulated sounds or words to express, say and convey thoughts, ideas and feelings. 
Furthermore, Tarigan (1990) states that: speaking is the skill to convey messages through spoken language.

From the definitions above, it can be concluded that speaking is the ability to say words in order to convey or express intentions, ideas, thoughts, and feelings that are compiled and developed according to the listener's needs so that what is conveyed can be understood by the listener. Speaking in English for Indonesians is not an easy thing, because when speaking English, the language learners not only have to think about the truth in grammar but also think about the social function of the spoken sentence, in speaking it is often done spontaneously. This difficulty in speaking English for non-native speakers is also raised by Celce and Mc Intosh in their book Teaching English as a Second or Foreign Language, saying that speaking fluency in English as a second language is the most difficult skill of all language skills for developed. Therefore, a new learning model is needed with English language materials integrated skills in the form of e-learning which provides activities for students to always practice independently every time and at any time.

There are several factors that influence the language learners in displaying speaking skills. In various studies, they mostly discussed about the factors that influence the language learners to speak foreign languages especially speaking in English. The language learners are reluctant to speak because it is influenced by several factors such as: fear of making mistakes when speaking, limited vocabulary to support them, shyness and nervousness or lack of confidence. This is because the language learners do not practice speaking enough. A lecturer must be able to apply the student-centred approach that the lecturer gives as much time as possible to give his students. The opportunity to do activities and speak optimally, even at the beginning of the semester the language learners are motivated to be brave and confident in speaking English even though there are still grammar errors.

In learning that uses online, student confidence in being able to use computers is also a success factor. The concept of computer self-efficacy is seen as an important variable for the study of individual behaviour in the field of information technology (Agarwal, et al. 2000). Computer self-efficacy can have a significant effect on the ability to use computers and students' emotional reactions to computers such as anxiety that arises when learning online. A person's computer self-efficacy may not be high immediately at the start of taking online subjects, as the findings of Lee \& Witta (2001) in their study of 16-year-old students who take online subjects, their self-efficacy changes significantly from beginning to the end of the semester. Therefore, the language learners must have the ability to overcome obstacles in online learning and not get frustrated and give up quickly until high self-efficacy of computer skills is achieved in online subjects. According to Compeu Higgins (1995) Computer Self-Efficacy (CSE) is defined as a judgment on a person's capability to use a computer or information system or information technology. Based on the social cognitive theory developed by Bandura (1986), it is not a judgment on a person's past in using a computer, but a judgment that will be made in the future. The results of Campeau \& Biggins's (1995) research show that there are three factors that can influence CSE, namely: (1) encouragement from other parties (2) other parties as users (3) support. Encouragement from other parties refers to groups and uses verbal persuasion. In the second factor, someone can increase their CSE by observing and imitating behaviour models. This is a powerful way to acquire behaviour as a learning model. The last factor is the existence of organizational support for computer users that can increase CSE. This support can be in the form of availability from the organization to help individuals who need increased abilities and self-perception of abilities. Campeau \& Biggins (1995) also explained that there are three dimensions of CSE, namely: (1) magnitude (2) strength and (3) generality. The dimension of magnitude refers to an individual using a variety of computer applications, while a specific CSE is the ability to create specific computer-related tasks in the general computing domain.

In order to break the chain of spreading Covid-19 in higher education, the Faculty of Medicine, Muhammadiyah University of Surabaya implemented online learning as a solution. Therefore, the purpose of this research described that the English language learners need online learning during the Covid-19 pandemic in Muhammadiyah University of Surabaya.

\section{RESEARCH METHOD}

This research used qualitative method which is related to true observation design with free writing that made a descriptive research design. The researchers were interested in describing the situation or case under his/her research study. It is a theory-based research design which is created by gathering, analyzing and presenting the collecting data. By implementing an in-depth research design such as this, the researchers can provide insights into the way and how of research. The research was conducted by first conducting a survey to the language learners regarding the application of online learning. The survey was distributed using a google form given to learners via WhatsApp messages. There are 80 subjects who had responded to the distributed survey. The survey results were then grouped into two categories of student responses: (1) Agree with the application of online learning; (2) Disagree with the application of online learning. According to Airy et al $(2010 ; 148)$ sample is a target of population. It means from a population that the researcher took a target to be observed. It is the qualitative method that consisted of a technique that was observation, then scoring from questionnaire and finally percent learners' responses. The aspects that were asked in the interview were: (1) The facilities and infrastructure owned by students to carry out online learning; (2) Student responses regarding the implementation of online learning using 
the English Discoveries platform; (3) Implementation of online learning in breaking the chain of Covid-19 spread in tertiary institutions. Analysis of the research data was carried out using the analysis model of Miles \& Huberman (1994) which consisted of three stages, namely data reduction, data display, and conclusion drawing and verification. The withdrawal and conclusion verification stage is the stage of interpreting research data to draw conclusions based on the phenomena obtained (Miles, MB, \& Huberman, M., 1994).

\section{RESULTS AND DISCUSSION}

1. Learners have adequate facilities to carry out online learning.

The increase in internet use in Indonesia is influenced by developments in information and communication technology (Rahadian, 2017). This data is relevant to the research results which show that even though there are students who do not have laptops, almost all students already have smartphones. The survey that has been conducted reports that all students in the medical faculty have both laptops and smartphones. The use of smartphones and laptops in learning online can improve student learning outcomes (Anggrawan, 2019). Pangondian, RA, Santosa, PI, \& Nugroho, E. (2019) stated that there are many advantages of using information and communication technology in the implementation of online learning, including that it is not bound by space and time. Many studies have been conducted that examine the use of devices such as smartphones and laptops in learning. The ability of smartphones and laptops to access the internet helps students to follow online learning (Kay \& Lauricella, 2011; Gikas \& Grant, 2013; Chan, Walker, \& Gleaves, 2015; Gokfearslan, Mumcu, Haslaman, \& Evik, 2016). The use of online learning used zoom cloud meetings has the advantage of being able to interact directly between students and lecturers. In this research, around 80 students used the zoom that has been facilitated by the medical faculty specifically for the lecturer.

Furthermore, the challenge of online learning is the availability of internet services. Most students access the internet using $\mathrm{Wi}-\mathrm{Fi}$, and a small proportion use a special cellular service for students who live in remote areas. When the online learning policy was implemented at Muhammadiyah University of Surabaya, students return home for study from home. They experienced cellular signal difficulties when in their rural areas, even if there was a signal that the learners got in their area was very weak. This is a challenge in itself in the application of online learning at Muhammadiyah University of Surabaya. Online learning had weaknesses when internet services are weak, and lecturer instructions are poorly understood by students (Astuti, P., \& Febrian, F., 2019). Therefore, the use of online learning used zoom cloud meetings for discussion that has the advantage of being able to interact directly between students and lecturers. In this research, around 80 students used the zoom that has been facilitated by the medical faculty at Muhammadiyah University of Surabaya.

2. The implementation of learning Online using English Discoveries platform.

The language learners got the opportunity to receive explanations through online activities for discussion via zoom and for sharing the topic via WhatsApp. They can use gadgets in real time which can be done anytime and anywhere with lecturer. The learners' computer self-efficacy skills, especially with learning models that was online was very important. Therefore, to achieve maximum learning outcomes, especially speaking skills, it was also determined by other factors such as communication strategies shown in figure 1 online learning via zoom. The other contributions in learning carried out online provide opportunities for learning together and separately (synchronous) or at the same time or different (asynchronous) which can be implemented through zoom. Therefore, this condition was able to increase variation in learning, forms student independence and interaction occurs between students and was able to motivate other students. Ideally mixed learning experiences should be participatory, not only interactive so that the cognitive and collaborative processes are both enhanced so that thinking and working together create quality learning (Allen, 2010).

In addition, the online learning model has several benefits, namely increasing teaching more effectively which can increase interaction between students and students, students and lecturers, the success of achieving learning goals, changing learning patterns that were previously teacher-centred to student-centred, providing independence in learning. and the interaction relationship between students and motivation to discipline themselves in online learning (Voos, 2003; Dziuban, et al. 2004; Murphy, 2003; Osguthorpe \& Graham, 2003; \& Sibley, 2003). In online learning, lecturers can check student learning outcomes directly through the Teacher Management System (TMS) so that lecturers can always provide feedback for each student's online learning progress as shown in figure 3 about the Teacher Management System (TMS).

It is development of higher education in Indonesia very fast and more advanced, of course, supported by many factors. One of the most influential factors in the world of education is technology and information. The existence of technology and information also brings benefits that can change the teaching and learning process for lecturers and learners. In this connection, lecturers and students must have extensive knowledge about computers and their technology applications, especially for online learning. In addition, special skills are needed to access and use them appropriately. The existence of abilities that the learners had related to the use of computers that can make them more confident and foster a sense of success in themselves to take courses 
that use computers, especially in online learning. Students' belief in their ability to use computers is called Computer Self Efficacy.

Several researchers, Johnston \& Joscelyn (1989), Kozma \& Johnson (1991), Perkins (1992) emphasize that the use of computers in a learning environment can increase learners to be actively involved in thinking and problem solving, increase understanding and mastery of learning, and more real learning. for increased knowledge construction. Likewise, research conducted by Papasraton \& Wangpipatwong (2006) concluded that self-efficacy and one's attitude towards computers are critical factors for the success of online learning. So that Computer Self Efficacy is an important factor because of the belief someone has about their ability to be able to carry out online learning. The results of this research supported the influence of online learning models and Computer Self Efficacy was an important factor for the frequency and success of using online learning and the higher a person's Computer Self Efficacy. Therefore, the learners who felt satisfied in online courses made the higher learning outcomes.

Accessing learning material was a very important aspect of practicing online learning. The use of PowerPoint still dominates the material used by lecturers who use WhatsApp groups to share with each other before being discussed in zoom. Devices to access online learning and learning materials are also important aspects of online learning practice. The application of the online learning model needed to be supported by the abilities that the learners had with regard to the use of computers that can make the learners more confident and foster a sense of success in itself to attend lectures that use computers, especially in online learning. The learners' confidence in their ability to use computers was called Computer Self Efficacy. Online learning model uses English Discoveries platform shown in figure 2 for accounts given to students according to their respective levels. Therefore, in learning using the English Discoveries platform, the learning is mix ability. In online learning using English Discoveries every week students must study 1 unit. In 1 unit there are about 7 lessons so that every day they have to complete 1 lesson for 3 steps, namely explore, practice and test. Based on activities that are routinely carried out by students every day, it can provide many opportunities to learn using online information technology, so that they can improve their English skills, especially speaking skills. online learning with a variety of content in English Discoveries that have been programmed.

The speaking skill is one of the language skills which relate to each other. The four skills of the language are:

1. Listening skills

2. Speaking skill

3. Reading skill

4. Writing skill (Nida, Harris, in Tarin, 1990)

Every language proficiency has a close relationship with the three proficiency in the other through a relationship regular order that first learn to listen to the language, and then speak, after learning to read and write. Speaking is one of the four abilities in language. The four language skills are: listening, speaking, reading and writing. These four skills cannot be separated. Basically, these four skills form a single unit called single chess (Tarigan, 2008). Speaking skill is closely related to listening skills and reading skills that are closely related to writing. Therefore, these four language skills are related. In the English Discoveries platform, integrated skills learning materials were packaged as shown in figure 4 for topics in daily life.

Kuo et al., (2014) stated that online learning is more student-centred which causes them to be able to bring up responsibility and autonomous learning. Learning online requires students to prepare their own learning, evaluate, organize and simultaneously maintain motivation in learning (Sun, 2014; Aina, M., 2016). Sobron, AN, \& Bayu, R. (2019) stated that online learning can increase student interest.

3 Implementation of online learning in breaking the chain of spreading Covid-19 in tertiary institutions. Various efforts to suppress the chain of Covid-19 spread in the campus environment, Muhammadiyah University of Surabaya applies online learning rules. The lectures are conducted using the internet, making it easier for lecturers and students to interact online. The lecturers provided an account of English Discoveries platform that can be accessed by the learners anywhere and anytime. According to Bell et al., (2017) online learning allows interaction via the web even though they are in far and different places (Arzayeva, et al., 2015). The existence of lecturers and students who are in different places during learning eliminates physical contact and is able to encourage the emergence of social distancing behavior. According to Stein (2020) doing social distancing as a good solution to prevent the spread of Covid-19. Implementation of online learning allowed the learners and the lecturers to carry out lectures from their own houses. The learners can access the lecture materials and send assignments given by the lecturer without having to meet physically on campus. This action can reduce the emergence of crowds on campus as happened in face-to-face lectures. WHO (2020) recommends that maintaining distance can prevent transmission of Covid-19. Online learning carried out at the Faculty of Medicine at Muhammadiyah University of Surabaya in an effort to break the chain of the spread of Covid-19 using learning applications that can be accessed via the internet network. Overall, the language learners satisfied with flexible learning. With online learning, the learners were not constrained by time and place where 
they can attend their lectures from their homes or from anywhere. With online learning, lecturers provide lectures through virtual classes that can be accessed anywhere and anytime, not bound by time and space. This condition allows the learners to freely choose which courses to take and which assignments to do first. Research by Sun et al., (2008) informs that the flexibility of time, learning methods, and place in online learning has an effect on student satisfaction with learning. Therefore, this action can reduce the emergence of crowds on campus as happened in face-to-face lectures. to maintain a distance that can prevent the transmission of Covid19.
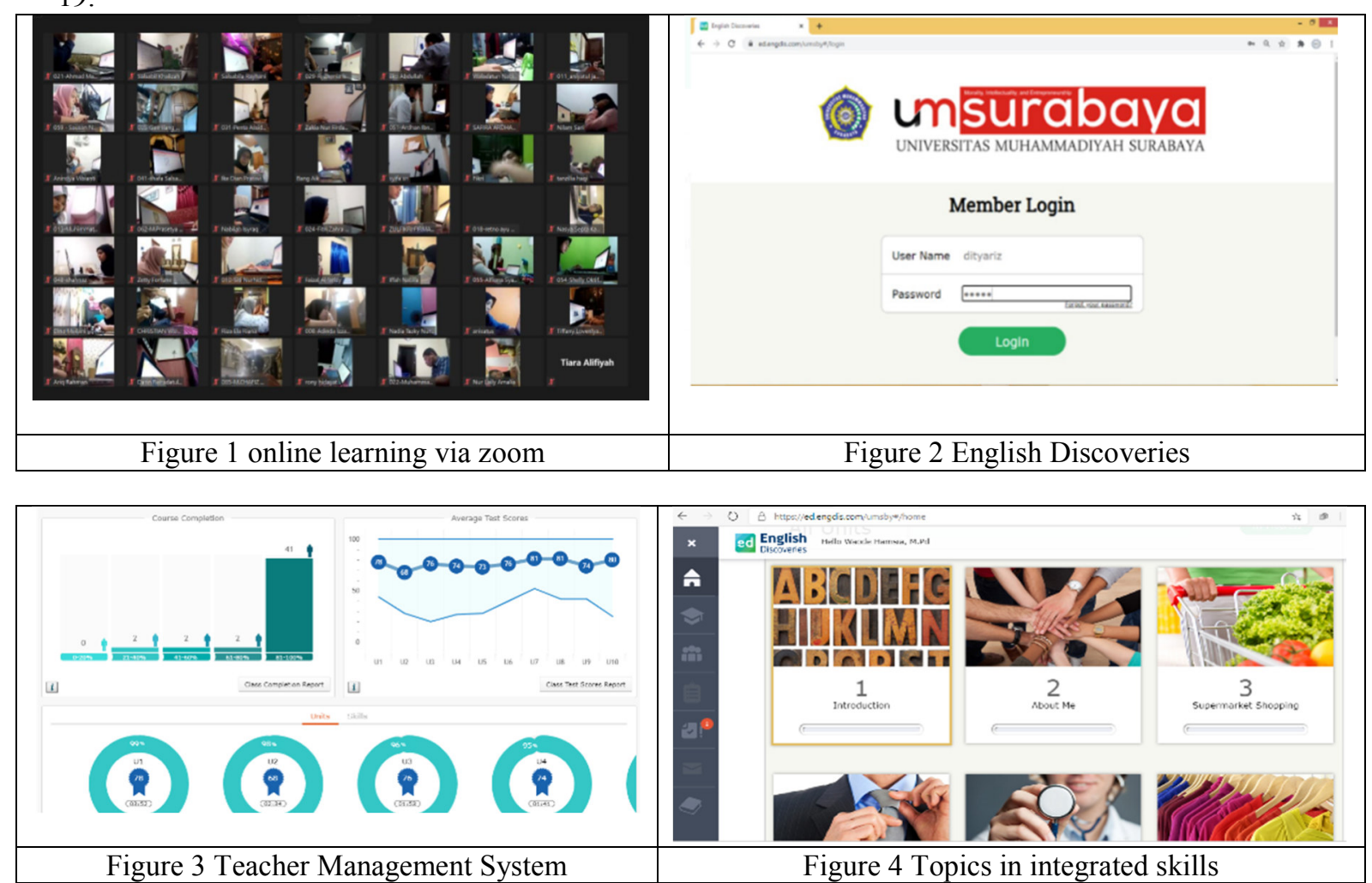

\section{CONCLUSION}

In order to break the chain of spreading Covid-19 in higher education, the medical faculty of the Muhammadiyah University of Surabaya implemented online learning as a solution for implementing learning. The results showed that the learners had the facilities and infrastructure to carry out online learning. Online learning was effective in addressing learning that allows lecturers and learners to interact in virtual classes that can be accessed anywhere and anytime. Online learning can make the learners learn independently and increase motivation. Based on activities that are routinely carried out by students every day, it can provide many opportunities to learn using online information technology. Therefore, they can improve their English skills because they have more time to practice their English, especially speaking skill. It is on line learning with a variety of content available on English Discoveries platform. On line communication method was between the lecturers and the learners, both asynchronous and synchronous. Asynchronous learning was a learning technique where online communication was carried out indirectly, while synchronous learning was carried out directly and in real time. The online communication method was used by the lecturers and the learners were dominated by a combination of asynchronous and synchronous learning. Various efforts to suppress the chain of Covid-19 spread in the campus environment, Muhammadiyah University of Surabaya applies online learning rules. Therefore, this action can reduce the emergence of crowds on campus as happened in face-to-face lectures that can maintain a distance that can prevent the transmission of Covid-19.

\section{ACKNOWLEDGMENTS}

The authors would like to express their deep gratitude to Muhammadiyah University of Surabaya for facilitating this research and also goes to IISTE which accepted and published this article.

\section{REFERENCES}

Agarwal, Rithu, V. Sambamurthy and RM Stair (2000), "Reserach Report: The Solving Relationship between General and Specific Computer Self Efficacy - An Empirical Assessment”, Information Systems Research, Vol.11, No. 4. 
Anggrawan, A. (2019). Analisis Deskriptif Hasil Belajar Pembelajaran Tatap Muka dan Pembelajaran Online Menurut Gaya Belajar Mahasiswa. MATRIK: Jurnal Manajemen, Teknik Informatika Dan Rekayasa Komputer, 18(2), 339-346. https://doi.org/10.30812/matrik.v18i2.411

Allen, MJ, \& Yen, WM (1979). Introduction to Measurement Theory. Monterey, Calif.: Brooks/Cole Pub. Co.

Arzayeva, M., Rakhimzhanov, K., Abdrahmanova, A., \& Umitkaliev, U. (2015). Special aspects of distance learning in educational system. Anthropologist, 22(3), 449-454. https://doi.org/10.1080/09720073.2015.11891900

Astuti, P., \& Febrian, F. (2019). Blended Learning Syarah: Bagaimana Penerapan dan Persepsi Mahasiswa. Jurnal Gantang, 4(2), 111- 119. https://doi.org/10.31629/jg.v4i2.1560

Bell, D., Nicoll, A., Fukuda, K., Horby, P., Monto, A., Hayden, F., ... Van Tam, J. (2006). Nonpharmaceutical interventions for pandemic influenza, national and community measures. Emerging Infectious Diseases. https://doi.org/10.3201/eid1201.051371

Bell, S., Douce, C., Caeiro, S., Teixeira, A., Martin-Aranda, R., \& Otto, D. (2017). Sustainability and distance learning: a diverse European experience? Open Learning, 32(2), 95-102. https://doi.org/10.1080/02680513.2017.1319638Arzayeva, et al., 2015

Burns, A., \& Joyce, H. (1997). Focus On Speaking. Sydney: National Center for English Language Teaching and Research.

Compeau, DR \& \& CA Higgins (1995). Computer Self Efficacy: Development of Measure and Initial Test”, MIS Quartley, Vol.19, No.12.

CZhang, D., Zhao, JL, Zhou, L., \& Nunamaker, JF (2004). Can e-learning replace classroom learning? Communications of the ACM. https://doi.org/10.1145/986213.986216

Darmalaksana, W. (2020). WhatsApp Kuliah Mobile . Fakultas Ushuluddin UIN Sunan Gunung Djati Bandung.

Firman, F., \& Rahayu, S. (2020). Pembelajaran Online di Tengah Pandemi Covid19. Indonesian Journal of Educational Science (IJES), 2(2), 81-89.

Gikas, J., \& Grant, MM (2013). Mobile computing devices in higher education: Student perspectives on learning with cell phones, smartphones \& social media. Internet and Higher Education. https://doi.org/10.1016/jjheduc.2013.06.002

He, W., Xu, G., \& Kruck, S. (2014). Online IS Education for the 21st Century. Journal of Information Systems Education.

Kay, RH, \& Lauricella, S. (2011). Exploring the Benefits and Challenges of Using Laptop Computers in Higher Education Classrooms: A Formative Analysis. Canadian Journal of Learning and Technology /La Revue Canadienne de 1 'apprentissage et de La Technologie. https://doi.org/10.21432/t2s598

Kuntarto, E. (2017). Keefektifan Model Pembelajaran Daring dalam Perkuliahan Bahasa Indonesia di Perguruan Tinggi. Indonesian Language Education and Literature, 3(1), 99-110. 10.24235/ileal.v3i1.1820

Kuo, YC, Walker, AE, Schroder, KEE, \& Belland, BR (2014). Interaction, Internet self-efficacy, and self-regulated learning as predictors of student satisfaction in online education courses. Internet and Higher Education. https://doi.org/10.1016/jiheduc.2013.10.001

Luoma, S. (2004). Assesing Speaking. Cambridge: Cambridge University Press. 212 pp. ISBN: 0-521-80487-6

Milman, NB (2015). Distance Education. In International Encyclopedia of the Social \& Behavioural Sciences: Second Edition. https://doi.org/10.1016/B978-0-08- 097086-8.92001-4 Molinda, M. (2005), Instructional Technology and Media for Learning New Jerse

Miles, MB, \& Huberman, M. (1994). Qualitative Data Analysis. Second Edition. SAGE Publications.

Moore, JL, Dickson-Deane, C., \& Galyen, K. (2011). E-Learning, online learning, and distance learning environments: Are they the same? Internet and Higher Education. https://doi.org/10.1016/jiheduc.2010.10.001.

Johnston, J. \& Joscelyn, MK (1989), The Computer Revolution in Teaching Accent on Improving College Teaching and Learning (ERIC Documents Reproduction Service No. ED474947)

Molinda, M. (2005). Instructional Technology and Media for Learning. New Jersey Colombus, Ohio

Oliver, R., Herrington, J., \& Reeves, T .(2005). Creating authentic learning environments trough blended learning aprroaches. Dalam C.Bonk \& c.graham (Eds.) handbook of Blended Learning : Global Perspectivez, Local Designs. New York: Jossey Bass.

Rahadian, D. (2017). Teknologi Informasi dan Komunikasi (TIK) dan kompetensi teknologi pembelajaran untuk pengajaran yang berkualitas. TEKNOLOGI PEMBELAJARAN, 2(1).

Stein, R. (2020). COVID-19 and Rationally Layered Social Distancing. International Journal of Clinical Practice. https://doi.org/10.1111/ijcp. 13501

Sun, PC, Tsai, RJ, Finger, G., Chen, YY, \& Yeh, D. (2008). What drives a successful eLearning? An empirical investigation of the critical factors influencing learner satisfaction. Computers and Education. https://doi.org/10.1016Zj.compedu.2006.11.007 Sun, SYH (2014). Learner perspectives on fully online language learning. Distance Education. https://doi.org/10.1080/01587919.2014.891428 
Tarigan, HG (1990). Berbicara: Sebagi Suatu Keterampilan Berbahasa. Cetakan ke- 10. Bandung: Angkasa Pangondian, RA, Santosa, PI, \& Nugroho, E. (2019). Faktor-Faktor Yang Mempengaruhi Kesuksesan Pembelajaran Daring Dalam Revolusi Industri 4.0. In Seminar Nasional Teknologi Komputer \& Sains (SAINTEKS) (Vol. 1, No. 1).

UNESCO. (2011). UNESCO ICT Competency Framework for Teachers. Paris; UNESCO.

WHO. (nd). Points of entry and mass gatherings. Retrieved March 28, 2020, from https://www.who.int/emergencies/diseases/novel-coronavirus 2019/technicalguidance/points-of-entry-andmass-gatherings 